\title{
German-Polish Borderscapes: Bordering and Debordering of Communication - An Example of Słubice
}

\author{
Barbara Alicja Jańczak ${ }^{1,2}$ \\ ${ }^{1}$ German-Polish Research Institute, European University Viadrina, Germany \\ ${ }^{2}$ Adam Mickiewicz University, Poland
}

Copyright $(2016$ by authors, all rights reserved. Authors agree that this article remains permanently open access under the terms of the Creative Commons Attribution License 4.0 International License.

\begin{abstract}
Due to the fact that Germany and Poland are both members of the Schengen Treaty, the role of the political borders between these two states has been reduced to a minimum. On account of the four freedoms, debordering processes have enabled the creation of borderscapes - places of transition, where time and space interact [7] and where cultures and languages underline a cross-border hybridization [6]. The aim of this paper is to present the linguistic behavior and communication strategies of Polish inhabitants on the German-Polish borderland. It presents the partial results of the research project which is being conducted on the Polish side of the German-Polish border. The analysis is focused on the communication strategies of the inhabitants of German-Polish borderscapes (on the example of Stubice inhabitants) and aims at answering the question about bordering (with reference to language choice and use) or debordering of communication as an everyday practice in German-Polish communication.
\end{abstract}

Keywords German-Polish Borderscape, Debordering of Communication, German-Polish Communication Strategies

\section{Introduction}

The fact that Germany and Poland are both members of the European Union and signatories of the Schengen Treaty reduces the role of the political borders between these two states to a minimum. ${ }^{1}$ On account of the four freedoms (free

\footnotetext{
${ }^{1}$ The regulations enabling border permeability have recently changed in some member states (2015) due to the overwhelming amounts of refugees. The states of the external Schengen Area especially are trying to protect their borders. However, border controls on the German-Polish border have not thus far been reinstated.
}

movement of goods, capital, services, and people), debordering processes have enabled the creation of borderscapes where cultural and linguistic diffusion may take place. The aim of this paper is to present the linguistic behavior and communication strategies of the Polish inhabitants of the German-Polish borderland, based on the example of the inhabitants of the border town of Stubice. These become manifest in the residents' choice of language.

In the Euroregions, Raasch [1] recommends the acquisition of the neighbor's language rather than the most popular language. Regional policy should support a "lingua culturalis instead of (cultureless) lingua franca" [1, p.14]. German should be for Poles, and Polish for Germans the linguae culturales. The question is whether reality mirrors the expectations. Dependent on the communication strategy towards the others (in the case of this study - towards German inhabitants) the communication in borderlands may be an example of bordering or debordering processes.

The analysis conducted in this study focuses on answering the following questions: What are the language relations between Poles and Germans? What are the communication strategies of the inhabitants of German-Polish borderscapes? Do interlocutors tend to put clear borders in their communication with reference to language choice and use, or is debordering (resulting in code-switching, or hybridization of communication forms) an everyday practice in German-Polish communication?

The paper presents the partial results of the author's research project, which is being conducted on the Polish side of the German-Polish border. ${ }^{2}$

\section{Borderscapes and (de)Bordering Processes}

\footnotetext{
2 The whole project (2013-2015) was financially supported by the German-Polish Science Foundation PNFN [2].
} 
The existence of borders and boundaries suggests the occurrence of bordering processes, whereas globalization is an indicator of debordering processes, as demonstrated by Popescu [5]. Bordering (or in the case of retaining significance - rebordering) consists of drawing or redrawing geographical, economic, social or cultural lines, whereas debordering focuses on the spatial, economic, social and cultural emergence of the world [5].

Due to the work of some researchers, inter alia Gracía Canclini [3], and also Gasparini [4], borderlands are often compared to laboratories. Gasparini [4, p.2-3] underlines that borderlands experience processes of multiculturalism and multilingualism more intensely than other areas. Nevertheless, an analysis of the research conducted on borderlands is sufficient to generalize on the subject at the macro (supranational) level [4]. ${ }^{3}$ Gracía Canclini [3] in turn focuses more on the processes of the transborder hybridity that illustrates the omnipresent globalization.

The existence of cross-border hybridization of cultures and languages are underlined by Mezzadra and Neilson [6]. Perera [7] refers to borderlands as zones where time and space interact and hybridization appears. He calls them borderscapes. Also Brambilla et al. [8] underline the necessity of understanding the concept of the border in time and space. They stress, after Brambilla [9], the "dynamic character of borders." Borderscapes are multidimensional, they are "constituted in different symbolic and material forms and functions as well as socio-political and cultural practices." [8, p.2] One should ask if the borderscape effects resulting in hybridity are also mirrored in language use.

\section{Method}

The paper focuses on only a small extract of empirical data collected in the framework of the author's research project in eight Polish border locations ${ }^{4}$ in 2014. The analysis concentrates on data from Stubice ${ }^{5}$. To examine the social dimension of bilingualism, the Polish inhabitants of the divided towns/villages, and the vendors at the border markets were recorded. The research on the inhabitants was conducted in the form of small talk (relying on short questions, mainly asking directions). In Słubice alone, 50 recordings were made. At the bazaars, the recordings focused on the greeting forms of Polish vendors.

Based on Nodari [10], Rössl [11] and ALTE [12], the author of this paper has created an analysis model of oral

\footnotetext{
3 Subsequently, the borderland serves for my theory as a language laboratory, where the language contact of two neighboring national groups can be evidenced more than in any other inland area.

4 The choice of research location was made according to the number of inhabitants living in a town or village (over 1,000 inhabitants) and its direct location on the German-Polish border with a German neighbor town or village on the other side. There are eight such places on the Polish side of the German-Polish border: 1. Świnoujście 2. Gryfino, 3. Kostrzyn nad Odra 4. Słubice 5. Gubin 6. Łęknica 7. Zgorzelec and 8. Porajów.

5 Stubice is a town with 18,000 inhabitants, located in the central part of the German-Polish border, directly neighboring the German twin town of Frankfurt on Oder on the other side of the Odra River.
}

communication competence in terms of receptive and, first of all, productive competence. The model is still in the editing phase.

\section{Communication Strategies by Kimura}

Communication strategies in the German-Polish border region, primarily in formal situations, have been analyzed by Kimura [13]. To determine the strategies, Kimura focuses on the choice of communication language. Depending on the frequency of occurrence, he presents different types of language constellations and indicates the three more frequent types. ${ }^{6}$ First, there is the symmetry of languages, relying on the use of German and Polish language with translation (this form occurs, however, in formal situations where translators are at the interlocutor's command). Kimura (2013) calls the second type asymmetry - use of one of the languages, in the German-Polish case German. The third type is the use of an external language the lingua franca, hence in the German-Polish case English. Rarely, one can notice the use of German and Polish as first languages or second languages, Polish as the partner's language or use of the Slubfurt ${ }^{7}$ language. ${ }^{8}$ The use of Sorbian and Polish without translation, or the planned language Esperanto is virtually insignificant.

Table 1. Constellation of languages on the German-Polish border by Kimura [13, p.115], translated by B. J.

\begin{tabular}{|c|c|c|c|}
\hline & often & seldom & quasi insignificant \\
\hline $\begin{array}{c}\text { 1. First } \\
\text { languages } \\
- \\
\text { symmetry }\end{array}$ & $\begin{array}{l}\text { German } \\
\text { and Polish } \\
\text { with } \\
\text { translation }\end{array}$ & $\begin{array}{c}\text { German and } \\
\text { Polish as first } \\
\text { languages without } \\
\text { translation } \\
\text { (receptive } \\
\text { bilingualism) } \\
\end{array}$ & $\begin{array}{l}\text { Sorbian and Polish } \\
\text { without translation } \\
\text { (Slavic } \\
\text { Interkomprehension) }\end{array}$ \\
\hline $\begin{array}{l}\text { 2. Internal } \\
\text { language - } \\
\text { asymmetry }\end{array}$ & German & $\begin{array}{l}\text { Polish (Partner } \\
\text { language) }\end{array}$ & - \\
\hline $\begin{array}{l}\text { 3. Partner } \\
\text { language - } \\
\text { symmetry }\end{array}$ & - & $\begin{array}{l}\text { German and } \\
\text { Polish as foreign } \\
\text { languages } \\
\text { (polyglot } \\
\text { communication in } \\
\text { foreign language) }\end{array}$ & - \\
\hline $\begin{array}{l}\text { 4. External } \\
\text { Language } \\
\text { - Lingua } \\
\text { Franca }\end{array}$ & English & $\begin{array}{l}\text { Slubfurt language } \\
\text { (mix of both } \\
\text { languages) }\end{array}$ & $\begin{array}{c}\text { Esperanto (planned } \\
\text { language) }\end{array}$ \\
\hline
\end{tabular}

The Slubfurt language is supposed to be a border variety that is made up of both languages. Kimura presents an

\footnotetext{
6 The table below presents four constellations of language contact occurring in formal situations, thereof only tree happen often.

7 The name was constructed by mixing the names of the twin towns Shub(ice)+(Frank)furt.

${ }^{8}$ The Slubfurt language is understood as a border variety that is made up of German and Polish. The detailed explanation is given in the paragraph below Table 1 .
} 
example of the variety that is postulated and promoted in the top-down logic by the Nowa Amerika Initiative that is characterized by numerous neologisms, intralexical code-switching and balanced use of both languages. The author of this paper finds it problematic, though, because the Slubfurt language perceived by Nowa Amerika in this form is an artificial construct that is not fountabled in reality. This comment does not negate the existence of certain groups of people, especially in the service sector, who tend (in their everyday practice) to mix both languages, and use a mixed language (which we might call Slubfurt language) as a common language strategy in the bottom-up logic. To these groups belong the vendors (in the border markets), hairdressers, motor mechanics and others.

The classification of the communication strategies by Kimura cannot be directly imported into the following analysis. Due to the fact that the author's research was conducted in informal situations, some of the communication strategies do not occur at all, or are rather unlikely to occur (i.e. German and Polish as first languages with translation). Also, the fact that the respondents answered a question posed in German excludes some language constellations. The possible communication strategies are primarily German as an internal language, German and Polish as first languages without translation, and English or the Slubfurt language as external languages. The analysis of the communication strategies will first of all refer to the choice of language that is influenced in most of the cases by knowledge of the language or language skills.

\section{Analysis of the Empirical Material}

The analysis of the communication strategies shows the linguistic behavior of the inhabitants of Stubice. All the respondents were Poles. 64\% of the respondents were female and $36 \%$ male. Their age was estimated by the interviewer. Over a half of the respondents were young persons, under 35 years $(58 \%)$. Only $10 \%$ of the respondents were estimated at over 60 years old.

50 persons were asked in German to explain how to get to the post office. Their answers were rated and catalogued on the basis of morphosyntactic, lexical and phonetic-phonological criteria into five categories of oral communication competence: competent/fluent, communicative speech production, basic speech production and (basic) comprehension - receptive skills and none language skills as shown in Table 2 below.

Even if, on the basis of a single statement, one cannot make a global picture of the linguistic competence of the respondent, the answers given may be classified and treated as an indication of it. However, the missing competences can be clearly distinguished.

Table 2. Oral communication competence by the author

\begin{tabular}{|c|c|c|c|c|c|}
\hline & \multicolumn{5}{|c|}{ Oral communication competence } \\
\hline & \multicolumn{3}{|c|}{ productive skills } & \multirow{2}{*}{$\begin{array}{l}\text { receptive skills } \\
\text { (basic) } \\
\text { comprehension }\end{array}$} & \multirow{2}{*}{$\frac{-}{\text { no language skills }}$} \\
\hline & $\begin{array}{l}\text { competent/fluent } \\
\text { speech production }\end{array}$ & $\begin{array}{c}\text { communicative speech } \\
\text { production }\end{array}$ & basic speech production & & \\
\hline \multirow{2}{*}{$\begin{array}{c}\text { Morphosyntactic } \\
\text { competence } \\
\text { - complexity of sentence } \\
\text { structures, } \\
\text {-word order: position of } \\
\text { verbs, } \\
\text { - congruence, } \\
\text {-syntax of noun phrase (use } \\
\text { of articles), } \\
\text { - morphologic forms } \\
\text { (inflexion) } \\
\end{array}$} & $\begin{array}{c}\text { - correct, complex } \\
\text { sentence constructions } \\
\text { (syntax) }\end{array}$ & $\begin{array}{c}\text { - simple sentences and } \\
\text { ellipsis }\end{array}$ & $\begin{array}{l}\text { - single words, ellipsis, } \\
\text { possible code switching }\end{array}$ & $\begin{array}{l}\text { - answer in Polish } \\
\text { or any other } \\
\text { language } \\
\end{array}$ & - \\
\hline & $\begin{array}{l}\text { - few morphosyntactic } \\
\text { errors (error frequency } \\
\text { under } 9 \% \text { ) }\end{array}$ & $\begin{array}{c}\text { - morphosyntactic } \\
\text { errors (error frequency } \\
10 \%-39 \%)\end{array}$ & $\begin{array}{c}\text { - numerous } \\
\text { morphosyntactic errors } \\
(\text { error frequency } 40 \%+)\end{array}$ & - & - \\
\hline $\begin{array}{l}\text { Lexical competence } \\
\text { - semantics and lexicon }\end{array}$ & $\begin{array}{c}\text { - varied vocabulary, going } \\
\text { beyond theme-related } \\
\text { lexicon }\end{array}$ & $\begin{array}{c}\text { - vocabulary matched } \\
\text { to the subject }\end{array}$ & $\begin{array}{l}\text { - only basic vocabulary, } \\
\text { lots of lexical gaps }\end{array}$ & - & - \\
\hline $\begin{array}{l}\text { Phonetic-phonological } \\
\text { competence } \\
\text {-rhythms } \\
\text {-sound differentiation }\end{array}$ & $\begin{array}{l}\text { - high } \\
\text { phonetic-phonological } \\
\text { accuracy }\end{array}$ & $\begin{array}{l}\text { - some errors in the } \\
\text { field of accentuation, } \\
\text { rhythm and sound } \\
\text { differentiation }\end{array}$ & $\begin{array}{l}\text { - numerous errors in the } \\
\text { field of accentuation, } \\
\text { rhythm and sound } \\
\text { differentiation }\end{array}$ & - & - \\
\hline
\end{tabular}


The recorded answers of the respondents have been classified according to the former categorization in the Table 3 below. ${ }^{9}$

If one superimposes the classification onto communication strategies identified by Kimura, one can see that most of the respondents acted according to the asymmetric pattern in German (see Table 3). Almost 48\% of utterances were produced in German. However, most of the utterances suggest communicative or basic oral competence, as the following example of speaker 49 illustrates in Table 4.

A quite frequent group of respondents used Polish as the first language - but in this case one can hardly assume receptive bilingualism as the communication form, due to the lack of language skills (proved by the difficulties in comprehension), as shown here below in the Table 5.

Only two respondents used the external language pattern, one respondent answering in English (speaker 50) and the second one using a language mix based on intrasyntactic code-switching (speaker 20). The following example in the Table 6 below illustrates the use of a mixed language strategy.

The recordings of the communication strategies on the streets of Słubice show that the main strategy is the choice between German and Polish, in other words, the asymmetric or symmetric solution. In both cases it is difficult to speak about debordering processes. Though the use of German shows openness towards the neighbor's language, this is unilateral and deepens the linguistic asymmetry of border communication (dominated by German). The symmetrical solution, i.e. the choice of Polish is, in the Stubice case, not proof of linguistic debordering, because in most of the cases it is caused by a lack of language competence, and it is probably quite an ineffective form of communication.

One can still find the examples of debordering processes proving the existence of the German-Polish borderscape. Mixing of both languages as a communication strategy resulting in debordering can be commonly observed in the service sector i.e. in the border markets. Language switching occurs on the inter- and intrasyntactic or even intralexical level. However intrasyntactic code-switching seems to be the most frequent. When analyzing the forms of greetings of Polish vendors in Słubice, one notices that many of them have only basic communication strategy in German. The most frequent communication strategy used by them is mixed language, based on frequent code-switching.

Table 3. Categorization of respondents' answers by the author

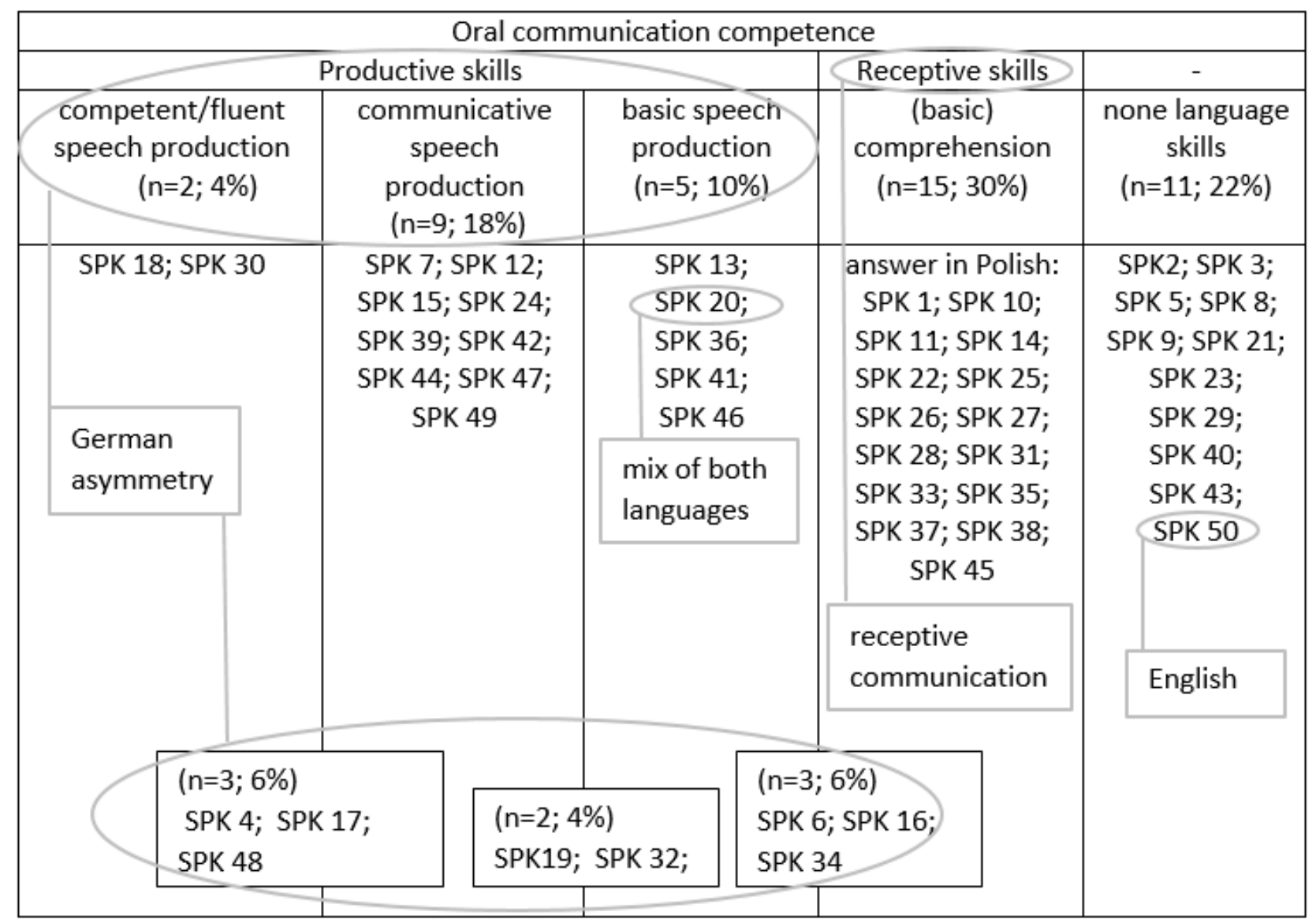

\footnotetext{
${ }^{9}$ The abbreviation SPK means 'speaker.'
} 
Table 4. Speaker 49, Stubice inhabitant, female, 20 years old. ${ }^{10}$

[1]

\begin{tabular}{|c|c|}
\hline & $0[00: 00.0]$ \\
\hline Interview. [v] & $((0,9$ S. $))$ Entschuldigung $((0,7$ S. $))$ Entschuldigung, $\bullet$ weißt Du wo die Post ist \\
\hline [trans] & I am sorry, Sorry, do you know where the post is \\
\hline
\end{tabular}

[2]

\begin{tabular}{|c|c|c|c|c|}
\hline &.. & $1[00: 04.2]$ & $2[00: 04.8]$ & $3[00: 05.1]$ \\
\hline Interview. [v] & hier • in der Nähe? & Vielleicht? & Ja. & \multicolumn{3}{|c|}{ here, nearby? Maybe? Yes } \\
\hline [trans] & \multicolumn{4}{|c|}{ Post? ((incomprehensible)) } \\
\hline SPK49 [v] & & Post? & ((unverständlich)) & ・ Ehm ((verzogen 0,8 S.)) \\
\hline [trans] & \multicolumn{4}{|c|}{} \\
\hline
\end{tabular}

[3]

\begin{tabular}{|c|c|c|c|c|c|}
\hline & .. & $4[00: 10.0]$ & $5[00: 10.7]$ & $6[00: 11.1]$ & $7[00: 11.4]$ \\
\hline Interview. [v] & & Also hier gleich? & & $\mathrm{Ja}^{\prime}$ & \\
\hline [trans] & \multicolumn{5}{|c|}{ So right here? Yes } \\
\hline SPK49 [v] & Post ist dorthin und rechts, & & Ja. & & Dort $\bullet$ eh und nt das \\
\hline [trans] & \multicolumn{5}{|c|}{ A post is there and right Yes There eh and nt that } \\
\hline
\end{tabular}

[4]

\begin{tabular}{|c|c|c|c|}
\hline &.. & $8[00: 16.6]$ & $9[00: 17.4]$ \\
\hline Interview. [v] & Ok. & \\
\hline SPK49 [v] & ist eh Wojska Polskiego Straße & & ・ Eh geradeaus, geradeaus und $((0,6$ \\
\hline [trans] & \multicolumn{2}{|c|}{ is eh Polish Army Street Eh straight on, straight on and } \\
\hline
\end{tabular}

[5]

\begin{tabular}{|c|c|c|c|c|}
\hline & $\ldots$ & $10[00: 22.4]$ & $11[00: 22.8]$ & $12[00: 23.4]$ \\
\hline Interview. [v] & Aber... & Ok. & \multicolumn{3}{|c|}{ But... } \\
\hline [trans] & \multicolumn{3}{|c|}{ Ehm } & Vielleist, ehm $\cdots$. das ist elm \\
\hline SPK49 [v] & S.)) an rechts ist $\bullet$ Post. $\cdots$ & \multicolumn{3}{|c|}{ on right is a post office Maybe ehm it is ahm } \\
\hline [trans] & \multicolumn{3}{|c|}{}
\end{tabular}

[6]

\begin{tabular}{|c|c|c|c|c|}
\hline & .. & $13[00: 28.7]$ & $14[00: 29.8]$ & $15[00: 30.4]$ \\
\hline Interview. [v] & & Ok. Das geht. & & \\
\hline [trans] & \multicolumn{4}{|c|}{ Ok. It is fine. ((Explanation of the project)) } \\
\hline SPK49 [v] & $(($ verzogen 0,9 S.) ) ein Kilometer. • & & Ja. & \\
\hline [trans] & \multicolumn{4}{|c|}{ one kilometer. Yes. } \\
\hline
\end{tabular}

[1]

Table 5. Speaker 28, Słubice inhabitant, male, about 50 years old.

\begin{tabular}{|c|c|c|c|}
\hline & $0[00: 00.0]$ & $1[00: 02.2]$ & $2[00: 04.4]$ \\
\hline Interview. [v] & Entschuldigung $\cdots$ & wissen Sie wo das Postamt ist hier in Slubice? & \\
\hline [trans] & I am sorry do you & know where the post office is here in Slubice? & \\
\hline SPK28 [v] & & & Bitte? \\
\hline
\end{tabular}

[2]

[3]

\begin{tabular}{|c|c|c|c|c|c|c|}
\hline & $3[00: 04.8]$ & $4[00: 05.8]$ & $5[00: 06.8]$ & $6[00: 07.7]$ & $7[00: 08.7]$ & $8[00: 10.4]$ \\
\hline Interview. [v] & Postamt? ・ & Posts & \multicolumn{7}{|c|}{ Ja, Post, ja } & Aber • \\
\hline [trans] & \multicolumn{7}{|c|}{ Post office? Post Yes, post, yes But } & eh to chodz, chodźs & \\
\hline SPK28 [v] & & Pocz/po & eh poczta? & & eh well come, come & \\
\hline [trans] & & Post/po & eh post? & & \\
\hline
\end{tabular}

\begin{tabular}{|c|c|c|c|c|}
\hline & .. & 9 [00:12.9] & $10[00: 13.7]$ & 11 [00:14.6] \\
\hline Interview. [v] & vielleicht zeigen, $\cdot$ einfach zeigen, wo das ist & & Ja, Postamt, • & ich muss \\
\hline [trans] & maybe show, just show, where it is & Yes, pos & ffice, I must & \\
\hline SPK28 [v] & & Poczta?・ & & Dobrato \\
\hline [trans] & & Post? & & Good \\
\hline
\end{tabular}

[4]

\begin{tabular}{|c|c|c|c|c|}
\hline & $12[00: 15.1]$ & $13[00: 15.6]$ & $14[00: 16.1]$ & $15[00: 17.6]$ \\
\hline Interview. [v] & & Oh nein & aber ich muss dahin noch $\boldsymbol{~}$ & \\
\hline [trans] & \multicolumn{3}{|c|}{ Oh no but I have to go there still } & A to nie, nie, nie. \\
\hline SPK28 [v] & chodź $\mathbf{k a w a}$ tek & \\
\hline
\end{tabular}

[5]

\begin{tabular}{|l|c|c|c|}
\hline &.. & $16[00: 20.0]$ & $17[00: 58.0]$ \\
\hline SPK28 [v] & $((1,2 \mathrm{~S}))$. & & \\
\hline
\end{tabular}

${ }^{10}$ Notation of different languages for all the tables and examples below: normal font-style - German, italic bold type - Polish, bold type - English, underlined - incorrectly produced words or morphemes. 
[1]

Table 6. Słubice inhabitant, female, about 50 years old.

\begin{tabular}{|c|c|c|c|}
\hline & $1[00: 00.6]$ & $2[00: 03.9]$ & $3[00: 05.7]$ \\
\hline Interview. [v] & Eh, wissen Sie wo die Post ist hier in Slubice? & Post? Postamt? & \\
\hline [trans] & \multicolumn{3}{|c|}{ Eh, do you know where the post is here in Slubice? Post? Post office? } \\
\hline SPK20 [v] & & $\mathrm{Ja} \cdot \mathrm{ja}, \mathrm{ja}$ & O jejku jak \\
\hline [trans] & \multicolumn{3}{|c|}{ Yes, yes, yes Oh gosh how } \\
\hline
\end{tabular}

[2]

\begin{tabular}{|c|c|c|c|c|}
\hline &.. & $4[00: 07.7]$ & $5[00: 09.3]$ & $6[00: 09.7]$ \\
\hline Interview. [v] & & & Ja & \\
\hline [trans] & & & Yes & \\
\hline SPK20 [v] & $t \boldsymbol{u}$ geh, $\bullet \boldsymbol{o}$ & $((1 \mathrm{~S})$.$) geradeaus$ & & $((0,6 \mathrm{~S})$.$) is eh ((1,2 \mathrm{~S})$.$) Geschäft Buscher,$ \\
\hline [trans] & \multicolumn{4}{|c|}{ here go straight on there is eh a store Buscher } \\
\hline
\end{tabular}

[3]

\begin{tabular}{|c|c|c|c|}
\hline & \multicolumn{2}{|c|}{7 [00:14.6] } & $8[00: 17.3]$ \\
\hline Interview. [v] & & Büchergeschäft, ja, Büchergeschäft, ja & \\
\hline [trans] & & Bookstore, yes, bookstore, yes & geradeaus \\
\hline SPK20 [v] & Bücher, Bücher eh • & Buhe, Buche, Buch, Buch jest (ich) Geschäft & \\
\hline [trans] & \multicolumn{2}{|c|}{ books, books eh Buhe, Buche (beech), a book, a book, there is (their) store straight on } \\
\hline
\end{tabular}

[4]

\begin{tabular}{|c|c|c|c|c|c|}
\hline & .. & $9[00: 19.8]$ & $10[00: 21.3]$ & $11[00: 21.7]$ & \\
\hline Interview. [v] & & Das ist links • & & $(($ lacht $))$ & Also \\
\hline [trans] & \multicolumn{5}{|c|}{ That is left ((laughs)) So } \\
\hline SPK20 [v] & und rechts $((0,9$ S. $))$ & & $A$ & Entschuldigen Sie links, ja, $\bullet$ ja $\bullet$ & Ja, $\boldsymbol{t o}$ \\
\hline [trans] & \multicolumn{5}{|c|}{ Oh I am sorry left, yes, yes } \\
\hline
\end{tabular}

[5]

\begin{tabular}{|c|c|c|c|c|c|}
\hline &.. & $13[00: 24.9]$ & $14[00: 26.5]$ & $15[00: 27.5]$ & $16[00: 28.7]$ \\
\hline Interview. [v] & die & & \multicolumn{4}{|c|}{ Also hier einfach } & ja und dann links & \\
\hline [trans] & \multicolumn{5}{|c|}{ That So simply here yes and then left } \\
\hline SPK20 [v] & tak & $\boldsymbol{\bullet} \bullet$ hier Sie gehen & geradeaus hier & Ja, ja, ja & und links ale müssen \\
\hline [trans] & \multicolumn{6}{|c|}{ so you go here straight on here yes, yes, yes and left but you must } \\
\hline
\end{tabular}

[6]

\begin{tabular}{|c|c|c|c|c|c|}
\hline &.. & $17[00: 31.7]$ & $18[00: 32.3]$ & $19[00: 32.7]$ & $20[00: 33.8]$ \\
\hline Interview. [v] & & $\mathrm{Mh} \mathrm{mh}$ & & $\mathrm{Mh} \mathrm{hm}((0,6 \mathrm{~S}))$. & \\
\hline SPK20 [v] & Sie gehen Geschäft Buche & & ja & & To tam kürze ist $\boldsymbol{d o}$ is \\
\hline [trans] & go store book & & yes & & So there short is to is \\
\hline
\end{tabular}

[7]

\begin{tabular}{|c|c|c|}
\hline & $21[00: 36.8]$ & $22[00: 41.3]$ \\
\hline SPK20 [v] & Straße jest takie jak to glówna, glówna, glówna Haupt? Haupt nie Haupt & \\
\hline [trans] & street is as this one main, main, main, main? Main not main? \\
\hline
\end{tabular}

[8]

\begin{tabular}{|c|c|c|c|c|c|c|}
\hline &.. & $23[00: 41.9]$ & $24[00: 42.2]$ & $25[00: 43.3]$ & $26[00: 43.8]$ & $27[00: 45.0]$ \\
\hline Interview. [v] & Hauptstra ße? & & \multicolumn{5}{|c|}{ Mh hm } & & \\
\hline [trans] & \multicolumn{7}{|c|}{ Main street? ((explanation of the project)) } \\
\hline SPK20 [v] & \multicolumn{7}{|c|}{ to jest takie glówna } & am links & ist Post. & \\
\hline [trans] & \multicolumn{7}{|c|}{ Hauptstraße } & \multicolumn{7}{|c|}{ Main such main on left there is a post office. } \\
\hline
\end{tabular}


In most cases the switch takes place on the inter- and intrasyntactic level, hence as code-switching. An example of such behavior is presented below:

Customer: Kleines Körbchen, konkret rund.

Vendor: $\quad \boldsymbol{A}$ rund? $\nearrow^{11}, \cdot$ ja, nie $\boldsymbol{m a} \boldsymbol{a} \cdot \bullet$ ganz kleine, Pl. Ger.------Ger. Pl.-Pl. Ger.---Ger.

$\boldsymbol{n i e}, \boldsymbol{i}$ andere kleine, $\boldsymbol{j}$ ja, mit Henkel ohne

Pl.-Pl. Ger.------------------------Ger.

- Ohne Henkel auch ist, nie, kleine, • ale obły.

Ger.------------Ger. Pl. Ger. Pl.----Pl.

Example 1, Bazaar Słubice, 2014

In some cases the switching occurs not only at the intraand intersyntactic level but also at the intralexical level:

Vendor 2: Komm $\boldsymbol{r}^{\prime} \boldsymbol{a} \boldsymbol{b a t} \boldsymbol{t}^{12}$. Rauch ${ }^{13}$ zwanzig Ger.Pl. Ger.------------Ger.

(Pfund) ((pause)) Hisch (Hirsch), o jest noch mit Ger.----------------Ger.Pl.-Pl. Ger.-Ger.

Knoblauch und Hisch $\boldsymbol{i}$ Hirsch auch mit Kräute.

Ger.--------------Ger. Pl. Ger.-----------------Ger.

Chcesz auch probieren bisschen Schynken?

Pl. Ger.--------Ger. IMG

Nie, ja? No bitte [bite]! ((pause)) Das wirklich gut,

Pl. Ger. Pl. Ger.-------------------------Ger.

das schmeckt naturale ohne Schimi (Chemie).

Ger.- --------------------------------------Ger.

((incomprehensive)) Heute ist nich so viel

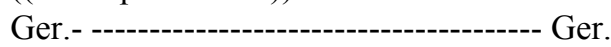

gute $\boldsymbol{r}^{\prime} \boldsymbol{a b a t}$ gebe, probiere noch diese gleiche

Ger. Pl. Ger. -------Ger.

[glaj e], wie die/den Hirsch, auch von Hirsch aber

Ger.--- -----------------------------------Ger.

mit Kräuter Pfeffer. Gemix (gemixt) gewürz

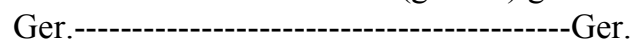

[gewerc].Masz, trzymaj, junge Damen auch, Ger. Pl.-------Pl. Ger.- ---------Ger.

-・ nicht so Deine Welt. Knoblauch verbessern ${ }^{14}$ ?

Ger.- ---------Ger.

Denn ich habe auch mit Knoblauch.

Ger.- --------------------or.

Example $2^{15}$, Bazaar Stubice, 2014

The word Szynken that seems to be quite often used for

${ }_{11}$ All the annotation marks has been explained in appendix.

12 Though the word "discount" sounds similar in Polish (rabat) and German (Rabatt) the accentuation on the first syllable and the pronunciation suggest its production in Polish language.

13 ((geräuchert -smoked?))

${ }_{14}$ Polish interference: poprawić czosnkiem - this time with garlic.

${ }^{15}$ Come discount. Smoke ((smoked?)) 20 pounds of venison, oh there is also with garlic and venison and venison also with spices. Would you like to try a bit of ham? No, yes? So please! It is really good. It tastes natural without chemical ingredients. Today there are not many people, good discount. Try also this is similar to the venison, but venison with pepper. Mixed spices. Here you are, take it young lady, it is not your world. This time with garlic? Cause I have also with garlic. ham by the local vendors can be determined as blending due to the superimposing of the grammatical and lexical features of both contact languages. ${ }^{16}$ Other words that seem to be constructed in a similar way i.e. recorded in the utterances of other vendors, are Schinetschken or Lachsschinetschken, cf. Jańczak [14]. The repetitive occurrence of mixing both languages indicates the use of mixed language as a communication strategy and the appearance of blended forms points towards hybridization as a debordering phenomenon.

\section{Conclusions}

Mezzadra and Neilson [6] as well as Perera [7] point out that borderlands are places of hybridity, in the author's opinion - also of linguistic hybridity. Research on language contact in the German-Polish border region (i.e. Kimura [13] and Jańczak [14]) as well as in other borderlands (i.e. Stern [15]) stresses the hybridization of communication of borderlands inhabitants which is manifested in frequent code switching and language mixing.

The results of the analysis on communication strategies of Stubice inhabitants show that $22 \%$ of the respondents (of which $36 \%$ are under the age of 25 and $55 \%$ over 60 years old) have no German language skills. $30 \%$ of respondents demonstrated elementary comprehension of the language. They chose Polish as a communication language with a German partner. In this case, we can scarcely speak about the strategy of receptive bilingualism - German and Polish as first languages. The most frequent communication strategy was the use of German as an internal language. Most of the respondents tried to answer in German (48\%), of which $24 \%$ in a communicative way, and $4 \%$ fluently. One person spoke in the lingua franca, English, and one person mixed both languages. The results of the communication strategies on the streets of Stubice do not confirm the use of the Slubfurt language as a common communication form.

However, the research into the greeting forms of Polish vendors from Słubice Bazaar proves that code-switching and mixing both languages are common communication strategies amongst certain groups of inhabitants of the border region. The analysis of the linguistic behavior of the vendors demonstrates the existence of a linguistically heterogeneous borderscape in which debordering processes are taking place.

In the author's opinion the presented study should be a starting point to carry out the comparative studies on communication strategies in further locations of the German-Polish borderland. The confirmation of the exi ${ }^{17}$ stence of language mixing and code switching strategies in further locations could suggest the existence of

\footnotetext{
${ }^{16}$ For a detailed discussion of blending phenomena see Jańczak [14].
} 
special linguistic routines along the German-Polish border.

\section{Appendix - Notation}

IMG - Interlinear Morphemic Glossing

$\nearrow$ - rising intonation

1 - Accentuation

- - short pause

- - longer pause

(()) - comments

() - presumable word

[] - phonetic transcription

\section{REFERENCES}

[1] Raasch , A. (2008). "Grenzkompetenz - von der Definition zur Evaluation zur Anwendung”, in: Bień-Lietz, M., Vogel, T. (eds.): Frühstart in die Nachbarsprache. Handbuch für den Spracherwerb in der deutsch-polnischen Grenzregion, Frankfurt (Oder), 9-15.

[2] PNFN, Polsko-Niemiecka Fundacja na rzecz Nauki, www.pnfn.pl (08.01.2016).

[3] Gracía, Canclini, N. (1999): La globalización imaginada. Mexico City.

[4] Gasparini, A. (1999/2000): "European Border Towns as Laboratories of Differentiated Integration", ISIG Quarterly of International Sociology, 4, 2-3.

[5] Popescu, G. (2012): Bordering and Ordering the Twenty-first Century. Understanding Borders. Lanham, Boulder, New York, Toronto, Plymouth.

[6] Mezzadra, S., Neilson, B., (2013): Border as Method, or, the multiplication of labor. Durham.

[7] Perera, S. (2007): “A Pacific Zone? (In)security, Sovereignty, and Stories of the Pacific Borderscape", in: Kumar Rajaram, P., Grundy-Warr, C. (eds.): Borderscapes: Hidden Geographies and Politics at Territory's Edge, Minneapolis, 201-227.
[8] Brambilla, Ch., Laine, J., Scott, J.W., Bocchi, G. (2015): "Introduction: Thinking, Mapping, Acting and Living Borders under Contemporary Globalisation", in: Brambilla, Ch., Laine, J., Scott, J.W., Bocchi, (eds.): Borderscaping: Imaginations and Practices of Border Making, London, 1-9.

[9] Brambilla, Ch. (2014): "Shifting Italy/Libya borderscapes at the interface of EU/Africa borderland: A 'genealogical' outlook from the colonial era to post-colonial scenarios", ACME - An International E-journal for Critical Geographies, 13(2), 220-245.

[10] Nodari, C. (2002): "Was heißt eigentlich Sprachkompetenz", Barriere Sprachkompetenz. Dokumentation zur Impulstagung vom 2. Nov. 01 im Volkshaus Zürich, SIBP Schriftenreihe Nummer 18, $9-14$.

[11] Rössl, B. (2007): "Sprachkompetenzmodell für 4;6-5;0 jährige Vorschulkinder”. Projektzentrum für Bildungsforsch ung,

http://www.roessl-linguistik.at/download/sprachkompetenz modell.pdf (08.01.2016).

[12] ALTE (Associacion of Language Testers in Europe) (2012): Handbuch zur Entwicklung und Durchführung von Sprachtests. Zur Verwendung mit dem GER. Erstellt im Auftrag des Europarats/Abteilung für Sprachenpolitik. Frankfurt am Main.

[13] Kimura, G.Ch. (2013): "Strategie komunikacji językowej na polsko-niemieckim pograniczu", in: Koutny, I., Nowak, P. (eds.): Language, Communication, Information, Poznań, 109-124.

[14] Jańczak, B. (2015): "German-Polish Border: Language Contact and Language Use on the Example of Forms of Address of Polish Vendors from Słubice Bazaar", in: Rellstab, D., Siponkoski, N. (eds.): Rajojen dynamiikkaa, Gränsernas dynamik, Borders under Negotiation, Grenzen und ihre Dynamik. VAKKI-symposiumi XXXV 12.13.2.2015. VAKKI Publications 4, Vaasa, 117-126.

[15] Stern, D. (2016): "Negotiating Goods and Language on Cross-Border Retail Markets in the Postsocialist Space", in: Kamusella, T., Nomachi M., Gibson C. (eds.): The Pelgrave Handbook of Slavic Languages, Identities and Borders. New York: Pelgrave, 495-523. 